\title{
Hierarchical forest management planning and sustainable forest management in the boreal forest
}

\author{
by Rebecca Tittler ${ }^{1}$, Christian Messier ${ }^{2}$ and Philip J. Burton ${ }^{3}$
}

\begin{abstract}
In keeping with international efforts to encourage sustainable forest management, new legislation, regulations, and certification criteria have been brought into effect across boreal regions of the world in the past decade or less. These initiatives have established hierarchical systems of forest management planning that consider multiple uses of the forest and various aspects of sustainable forest management at different scales. We describe the systems established in Quebec, Ontario, Saskatchewan, Alberta, and British Columbia, Russia, Finland, and Sweden. Most jurisdictions employ some form of three-level planning framework, in which strategic, tactical, and operational plans and considerations are presented with successively greater detail and spatial explicitness. However, planning scales and time horizons vary considerably, as does the level of consideration given to biodiversity and social concerns. We examine these systems in the context of sustainable forest management, raising a number of questions to be addressed in future research, adaptive management, and policy reform. In particular, we note (1) a need of new landscape and regional planning tools to evaluate the long-term and large-scale impacts of various land uses and (2) a general lack of responsiveness to global carbon and climate change concerns.
\end{abstract}

Key words: forest management planning, sustainable forest management, boreal forest, forest policy, planning hierarchies, hierarchical planning

Afin de demeurer en ligne avec les efforts internationaux pour encourager l'aménagement forestier durable, de nouvelles lois, règlements et critères de certification ont été mis en vigueur dans toutes les régions boréales du monde au cours de la dernière décennie. Ces initiatives ont mis en place des systèmes hiérarchisés de planification de l'aménagement forestier qui considèrent les multiples utilisations de la forêt et les différents aspects de l'aménagement forestier durable selon des échelles variables. Nous décrivons les systèmes mis en place au Québec, en Ontario, en Saskatchewan, en Alberta, et en Colombie-Britannique, ainsi qu'en Russie, en Finlande et en Suède. La plupart des juridictions utilise une certaine forme de cadre de planification à trois niveaux, dans lequel, les plans stratégiques, tactiques et opérationnels ainsi que les considérations sont présentés successivement avec plus de détail et de précisions spatiales. Toutefois, les échelles de planification et les horizons temporels varient considérablement, comme c'est le cas pour le niveau de considération accordée à la biodiversité et aux questions sociales. Nous examinons ces systèmes dans le contexte de l'aménagement forestier durable, tout en soulevant plusieurs questions qui devront être traitées par la recherche dans le futur, l'ajustement de l'aménagement et la réforme des politiques. Nous soulignons particulièrement (1) la nécessité d'avoir de nouveaux outils de planification au niveau du paysage et des régions étudiées afin d'évaluer les impacts à long terme et à grande échelle des multiples utilisations du territoire et (2) un manque généralisé de sensibilité en matière de carbone total et de changements climatiques.

Mots-clés : planification de l'aménagement forestier, aménagement forestier durable, forêt boréale, politique forestière, hiérarchie de planification, planification hiérarchisée

\section{Introduction}

Until the 1990s, most countries managed their forests under the principle of "sustained yield," which was concerned almost exclusively with timber yield. However, in the past decade, those who create policy have come to realize the importance of multiple uses of the forest and to appreciate the many services the forest provides, such as carbon sequestration. This change in atti-

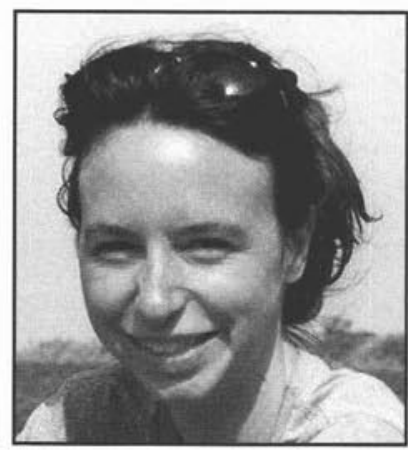

Rebecca Tittler

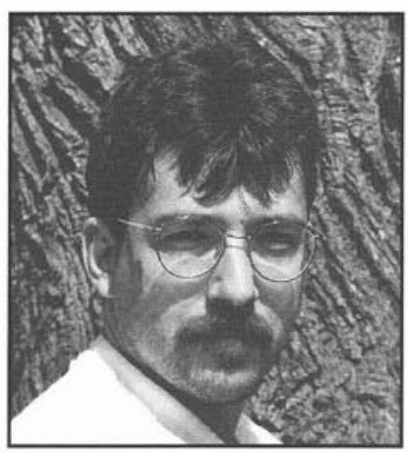

Christian Messier

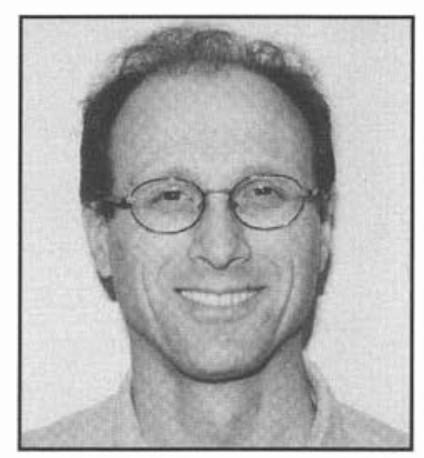

Philip J. Burton tude has led to a shift from sustained timber yield to sustainable forest management approaches to forestry. "Sustainable

\footnotetext{
${ }^{1}$ Department of Biology, Carleton University, 1125 Colonel By Drive, Ottawa, Ontario K1S 5B6. E-mail: rtittler@chat.carleton.ca

${ }^{2}$ Groupe de recherche en écologie forestière interunniversitaire, Université de Québec à Montréal, C.P. 8888, Succ. Centre-ville, Montréal, Quebec H3C 3P8. E-mail: messier.christian@uqam.ca

${ }^{3}$ Symbios Research \& Restoration, P.O. Box 3398, Smithers, British Columbia VOJ 2N0 E-mail: symbios@bulkley.net
}

forest management" is generally defined as the management of the forest with the aim of meeting the social, ecological, and economic needs of present human populations without compromising the needs of future generations. Community participation and transparency are often cited as key to sustainable forest management, as are the identification of threatened habitats and forest ecosystems, the protection of rare species and habitats, the maintenance and/or enhancement of forest cover and health, and the incorporation of knowledge about non-wood forest resources. 
The shift in attitude from sustained yield to sustainable forest management approaches to forestry was reflected at an international level at the Earth Summit in Rio de Janeiro in 1992 with the adoption of the Forest Principles and Chapter 11 of Agenda 21. These initiatives stressed the importance of sustainable forest management and, as the first international consensus on forest issues, have led to various national and international attempts to identify criteria and indicators of sustainable forest management. Many of the non-European boreal and temperate forest countries, including Canada and the U.S., are participants in the Montreal Process (Montreal Process 1995), while the European countries, including Sweden and Finland, are participants in the Helsinki or Pan European Process to identify criteria and indicators (United Nations Commission on Sustainable Development 1996). Russia is the only country to participate in both processes. These international processes have led to agreed-upon lists of criteria of sustainable forest management, the Montreal Process through the Santiago Declaration of 1995 and the Pan European Process through Resolution L2 of the Third Ministerial Conference on the Protection of Forests in Europe signed in Lisbon in 1998. The six common agreed-upon criteria are the maintenance, conservation, and/or enhancement of (1) biological diversity, (2) forest health and vitality, (3) forest productive functions (e.g., soil and water), (4) the capacity of the forest to produce wood and non-wood products, (5) global carbon cycles, and (6) the socio-economic functions of the forest (United Nations Commission on Sustainable Development 1996). Practical indicators of these criteria have also been developed and are being tested through programs such as Canada's model forest program (Canadian Forest Service 2000).

Although none of the UN or UN-spawned declarations and resolutions are legally binding, new forestry legislation, regulations, and certification criteria have emerged in most boreal jurisdictions in keeping with the shift from sustained yield to sustainable forest management in the past ten years. Among the factors affected has been the forest management planning process. Although they vary among countries and provinces and with forest ownership systems, standard planning processes are hierarchical, involving multiple scales and steps, and most now span larger temporal and spatial scales than they did ten years ago. Many of the planning processes are also more transparent than they used to be, with public input and local knowledge solicited at various stages. We examine and compare the current planning processes among various political jurisdictions in the boreal forest and touch on the question of whether they are suitable for the implementation of sustainable forest management practices in the vast and globally important boreal biome. We focus on the Canadian provinces of Quebec, Ontario, Saskatchewan, Alberta, and British Columbia, and on Sweden, Finland, and Russia, which are collectively responsible for most of the active forest management in the boreal forest.

\section{The Hierarchy of Forest Planning across Political Boundaries \\ Canada}

In Canada, $94 \%$ of the forest is publicly owned, $71 \%$ by the provinces in the form of provincial crown land and $23 \%$ by the federal government in the form of national parks or forest land in the territories. The federal government is responsible for any private forestry or First Nations community forestry and has set standards for sustainable forest management through the National Forest Strategy $(1992,1998)$, but the legislation regulating forest management planning on provincial crown land is provincial. Among the five provinces examined here, the percentages of the forest in the form of crown provincial land are as follows: Quebec: $89 \%$; Ontario: $88 \%$; Saskatchewan: 97\%; Alberta: 87\%; British Columbia: 95\% (Canadian Forest Service 2000).

The new provincial legislation regulating forest management in Canada's boreal provinces generally sets sustainable forest management as the guiding principle, and the different acts and regulations discuss most or all of the six criteria described above. The Quebec Forest Act (1996) states the promotion of "sustainable forest development" as its main purpose, and includes all six of the common criteria for sustainable forest management in a detailed definition of this term. The Ontario Crown Forest Sustainability Act (1994) states the main purpose of the act as the promotion of "sustainability," defining this in terms of the principles of conserving forest health and productivity, biological diversity, ecological processes, water, soil, and social, economic, and cultural values. The only sustainable forest management criterion not mentioned is the conservation and maintenance of global carbon cycles, although this may be understood to be included under "ecological processes." The Saskatchewan Forest Resources Management Act (1996) states the promotion of "sustainable use" as its main purpose, defining this in terms of economic, social, and cultural needs. It stresses the importance of conservation and maintenance of forest health and vitality, wood and non-wood forest resource production, multiple uses, and stakeholder input, but does not mention biological diversity, soil, water, or global carbon cycles. The British Columbia Forest Practices Code (1995) states "sustainable use" of the forests as its main management objective, defining sustainability with reference to all the above criteria of sustainable forest management except the conservation and maintenance of global carbon cycles. The amended B.C. Forest Act (1996) reiterates that these five criteria must be the basis for management on provincial Crown land. Finally, although the Alberta Forests Act (1996) is based on sustainable yield, the 1998 Interim Forest Management Planning Manual has since been published to introduce sustainable forest management as the guiding principle of forest management. This planning manual discusses all the criteria of sustainable forest management except the conservation and maintenance of global carbon cycles.

Although there are some variations, the provincial forest management planning processes generally adhere to the following pattern: (1) the provincial government passes forestry acts and regulations and develops forest management policies; (2) based on these policies, the provincial government then creates large-scale land use plans and strategies with the input of stakeholder groups and communities for some or all areas; (3) the provincial government carries out forest inventories; (4) timber rights are granted to industry in the form of Forest Management Agreements (FMAs) or licenses, with industry agreeing to periodically produce long-term strategic management plans and five-year and annual operating plans; (5) the provincial government monitors and inspects industrial operations. Public input is generally solicited in the development of policies, land use plans and strategies, and long-term strategic management 
plans (Canadian Forest Service 2000). All plans must be consistent with the higher level plans, i.e., long-term strategic plans must be consistent with land use plans (where they exist), five-year plans with long-term strategic plans, and annual plans with five-year plans. The annual allowable cut is set by the provincial governments or agreed upon by the governments and the industry every five or ten years, supposedly at a level that is consistent with the sustainability of timber and non-timber forest resources.

Land use plans are designed to provide long-term strategies for regional land use and landscape management. They are supposed to present an environmental, cultural, economic, and social context for all forms of further land use and industrial development, including forest management. They are designed to be long term, but vary in the number of years they cover. In fact, term and renewal/revision periods are generally not specified (Table 1). Land use plans set forth objectives, goals, principles, and strategies for land use and management and describe the planning area and its present and future uses. They typically map a variety of current resource values and future development options and constraints, usually in the form of designated land use or resource emphasis zones. In Quebec and Saskatchewan, land use plans are prepared for all Crown land (Quebec Act Respecting the Lands in the Public Domain 1987, Saskatchewan Forest Resources Management Act 1996), whereas in Ontario and British Columbia, they are only prepared for some areas (Ontario Public Lands Act 1990, Forest Practices Code of British Columbia 1995). The only province considered that does not have specific legislation on land use plans is Alberta (Alberta Public Lands Act 1980) (Table 1).

The typical long-term strategic plan presents a long-term strategy for the sustainable management of a forest tenure or management unit for a period of 20 (e.g., Ontario and Saskatchewan) or 25 years (e.g., Quebec) (Table 1). It describes the management unit from an environmental, social, and economic point of view, including the identification of essential habitat and other sensitive areas or natural areas to be protected. It must also discuss other forest resources and non-timber uses of the forest. While not necessarily a total resource inventory or a rotationlong outline of management activities, a strategic plan must nevertheless include a description of the forest (or management unit) in which the harvest is planned and of the main infrastructure necessary to support this harvest, and it must describe overall forest management goals and management and silvicultural activities. This plan must also specify how forest management operations will be monitored and the renewal of the forest will be assessed at the industrial level. Production of the plan involves a public consultation process for all provinces but Saskatchewan. In some provinces, details on insect, disease, and fire management (Quebec and Saskatchewan), monitoring (Ontario and Alberta), traditional and current land uses (Ontario and Saskatchewan), and reforestation (Ontario, Alberta, and Saskatchewan) must also be included at this stage.

Typically, the five-year operating plans provide more detail on the actual silvicultural and management activities to be carried out, and generally include maps indicating the locations of the planned operations and roads to be used, maintained, and built, as well as any protected or sensitive areas. For all provinces but Quebec, this stage must include infor- mation on fire management, and in Ontario and British Columbia, these plans must also describe any planned disease and insect management. (As noted above, fire management, insect, and disease issues are dealt with at the long-term strategic planning level in Quebec and Saskatchewan.) In some provinces, development of five-year plans includes a public consultation process (Quebec, Ontario, and B.C.), and, like the strategic plans, they must provide information on renewal and reforestation (Ontario, Alberta, and Saskatchewan) and monitoring (Alberta and Saskatchewan). In Alberta and Saskatchewan, these plans must specifically describe how other uses and users of the forest have been taken into account in plan development.

Annual plans provide still more detail at a finer scale. These plans range from simple logging plans to complex silvicultural prescriptions. They must describe planned harvesting, silvicultural and other management activities for the next year, and all but those produced for Saskatchewan forests must include information on reforestation and renewal (Saskatchewan deals with this issue at the five-year planning stage). They must also provide maps indicating stands to be logged and roads or other access corridors to be used and developed. In all provinces but British Columbia, other uses of the forest must be taken into account at this stage as well as at earlier stages.

In Alberta, the long-term strategic planning process is slightly different (Table 1). Every 10 years or less, FMA holders are required to produce a detailed forest management plan that covers a period of 140 to 200 years. This plan is subject to the approval of the Alberta Department of Environmental Protection. For Forest Management Units (FMUs) that are not under FMA tenure, Alberta Environmental Protection prepares long-term forest management plans. It is the responsibility of Alberta Environmental Protection to set the allowable rate of cut for all land owned by the province. Alberta's long-term plans are similar to the standard 20- to 25-year plans described above. They present a resource management philosophy, resource management goals, management objectives, and an implementation strategy; they describe how the program will be regularly monitored and how the management strategies will be evaluated in a defined geographical region; and finally, they must consider social, economic, and environmental issues and must be developed with public participation (Alberta Environmental Protection 1998).

When an FMA is initially granted in Alberta, an interim preliminary forest management plan must be submitted within 12 months of the signing, before logging under the authority of the FMA may begin. This plan commonly involves public participation but does not strictly require a public review process. It establishes the interim harvest level and describes how it was determined, identifies management objectives and strategies, describes new inventories to be carried out to develop the detailed forest management plan, and includes terms of reference. These terms of reference present a plan for development of the detailed forest management plan; they describe how, when, and why the detailed forest management plan will be developed and by whom, what products will be produced, and how the public will be involved in the planning process (Alberta Environmental Protection 1998).

In British Columbia, the industrial strategic planning and the governmental land-use planning stages may be merged (Table 1), i.e., the Lieutenant Governor in Council or the ministers may declare existing Land and Resource Management 
Table 1. The hierarchical forest management planning processes in the various countries and Canadian provinces that log in the boreal forest

\begin{tabular}{|c|c|c|c|c|c|c|}
\hline State & Owner & Plan & $\begin{array}{l}\text { Prepared/ } \\
\text { submitted } \\
\text { by }\end{array}$ & Scale & $\begin{array}{l}\text { Term } \\
\text { (yrs) }\end{array}$ & $\begin{array}{c}\text { Renewal/ } \\
\text { revision } \\
\text { period (yrs) }\end{array}$ \\
\hline \multirow[t]{4}{*}{ Quebec } & Public & Land Use plan ${ }^{R}$ & Government & Regional $^{1}$ & $\begin{array}{l}\text { Unspecified } \\
\text { (long-term) }^{2}\end{array}$ & Unspecified \\
\hline & Public & General plan ${ }^{R}$ & Industry & Regional & 25 & 5 \\
\hline & Public & Five-year plan ${ }^{R}$ & Industry & Landscape $^{3}$ & 5 & 5 \\
\hline & Public & Annual plan ${ }^{R}$ & Industry & Stand $^{4}$ & 1 & 1 \\
\hline \multirow[t]{3}{*}{ Ontario } & Public & Land use plan ${ }^{\vee}$ & Government & Regional & $\begin{array}{l}\text { Unspecified } \\
\text { (long-term) }\end{array}$ & Unspecified \\
\hline & Public & Forest management plan ${ }^{R}$ & Industry & $\begin{array}{l}\text { Regional/ } \\
\text { Landscape }\end{array}$ & $20 / 5$ & 5 \\
\hline & Public & Annual Work Schedule ${ }^{R}$ & Industry & Stand & 1 & 1 \\
\hline \multirow[t]{4}{*}{ Saskatchewan } & Public & Forest Accord ${ }^{\mathrm{R}}$ & Government & Provincial & $\begin{array}{l}\text { Unspecified } \\
\text { (long-term) }\end{array}$ & 10 \\
\hline & Public & Integrated forest land use plan ${ }^{R}$ & Government & Regional & $\begin{array}{l}\text { Unspecified } \\
\text { (long-term) }\end{array}$ & 5 \\
\hline & Public & 20-year forest management plan $R$ & Industry & Landscape & 20 & 10 \\
\hline & Public & Operating plan ${ }^{\mathrm{R}}$ & Industry & Stand & $\begin{array}{l}5 \text { (with more detail } \\
\text { on year } 1)\end{array}$ & 1 \\
\hline \multirow[t]{3}{*}{ Alberta } & Public & Forest management plan ${ }^{R}$ & $\begin{array}{l}\text { Government/ } \\
\text { Industry }\end{array}$ & Regional & $140-200$ & 10 \\
\hline & Public & General development plan ${ }^{R}$ & Industry & Landscape & 5 & 1 \\
\hline & Public & Annual operating plan ${ }^{R}$ & Industry & Stand & 1 & 1 \\
\hline \multirow[t]{3}{*}{ British Columbia } & Public & Higher level plan $\mathrm{s}$ & Government & Regional & $\begin{array}{l}\text { Unspecified } \\
\text { (long-term) }\end{array}$ & Unspecified \\
\hline & Public & Forest development plan ${ }^{R}$ & Industry & Landscape & 5 & 1 \\
\hline & Public & Silvicultural prescription ${ }^{R}$ & Industry & Stand & 1 & 1 \\
\hline \multirow[t]{2}{*}{ Russia } & Public & $\begin{array}{l}\text { Forest management and development } \\
\text { plan } \mathrm{R}\end{array}$ & $\begin{array}{l}\text { Government (paid } \\
\text { for by industry) }\end{array}$ & Landscape & $1-49$ & $1-49$ \\
\hline & Public & Annual logging plan ${ }^{R}$ & $\begin{array}{l}\text { Government (paid } \\
\text { for by industry) }\end{array}$ & Stand & 1 & 1 \\
\hline \multirow[t]{7}{*}{ Finland } & Private & Forestry Objective Program ${ }^{R}$ & $\begin{array}{l}\text { Regional forestry } \\
\text { centres }\end{array}$ & Regional & Unspecified & $\leq 5$ \\
\hline & Private & Estate-level plan $\mathrm{V}$ & Private landowners & $\begin{array}{l}\text { Landscape/ } \\
\text { Stand }\end{array}$ & 10 & 5 \\
\hline & Private & Long-term forest management plan ${ }^{\mathrm{V}}$ & Industry & Landscape & 30 & 1 \\
\hline & Private & Short-term forest management plan $\mathrm{V}$ & Industry & Stand & 10 & 1 \\
\hline & Public & Natural resources management plan ${ }^{R}$ & Government & Regional & 10 & 5 \\
\hline & Public & Landscape ecological plan ${ }^{R}$ & Government & Landscape & $\geq 50$ & 5 \\
\hline & Public & Operating plan ${ }^{R}$ & Government & Stand & 1 & 1 \\
\hline \multirow[t]{4}{*}{ Sweden } & Private & Long-term forest management plan $\mathrm{V}$ & Private landowners & Landscape & 10 & Variable \\
\hline & Private & Strategic plan $\mathrm{V}$ & Industry & Landscape & 100 & 10 \\
\hline & Private & Tactical plan $\mathrm{V}$ & Industry & $\begin{array}{l}\text { Landscape } \\
\& \text { Stand }\end{array}$ & $3-10$ & $3-4$ \\
\hline & Private & Operating plan $\mathrm{v}$ & Industry & Stand & $1-3$ & $\leq 1$ \\
\hline
\end{tabular}

${ }_{\mathrm{R}}$ Required by law.

v Voluntary.

${ }^{S}$ Required, but only for some areas.

${ }^{1}$ By "regional" we mean a large scale or a forest-wide scale, with boundaries either along political or ecological borders. In Finland, this means an area of 100000 -500000 ha (Nordic Council of Ministers 1999a), whereas in Canada, this may mean millions of hectares (e.g., Alberta Pacific Forest Industries 2000).

2"Unspecified (long-term)" generally means 50-100 years or longer.

${ }^{3}$ By "landscape" we mean medium-scale, generally defined more along ecological than political boundaries. In Canada, this often means entire FMAs or land tenures, which may also add up to millions of hectares. In Finland, a landscape is defined as 40 000- 100000 ha in size (Nordic Council of Ministers 1999a), and in Sweden, $5000-30000$ (Nordic Council of Ministers 1999b).

${ }^{4} \mathrm{~A}$ stand is the finest scale considered. Although stands are sometimes defined in terms of arbitrary or regulated cutblock sizes or sites rather than in ecological terms, they generally do not exceed $\sim 200 \mathrm{ha}$. Note that when a plan is said to be stand-level, it generally covers a whole series of individual stands, as well as the infrastructure that connects them.

Plans or Regional Land Use Plans to be higher level forest management plans if they judge that they qualify as higher level forest management plans, as described in the regulations (British Columbia Ministry of Forests 1996). Regardless of whether or not they originate as land use plans, higher level plans are prepared by government staff through a multiple stakeholder roundtable process, and must be approved by the B.C. Ministry of Forests, the B.C. Ministry of Environment, Lands 
and Parks, and sometimes other ministries. Like other higher level and land use plans, they provide a strategic context and general objectives for all other management plans and are developed with extensive public input. They vary in length of tenure and in content, but in general are designed to provide long-term strategies for regional land use and landscape management (British Columbia Ministry of Forests 1996).

Finally, the government of Saskatchewan has added a higher-level step to the process (Table 1). Under the new Saskatchewan Forest Resources Management Act (1996) and the revised Forest Resources Management Act and Regulations (1999), the government of Saskatchewan has agreed to prepare a provincial Forest Accord every 10 years to establish long-term principles, policies, and goals for forest management in the province. This accord is designed to provide a broad framework for other forest management plans, and is produced with much public and stakeholder involvement. The Forest Policy Framework released in 1994 will serve as a model for these accords (Forest Resources Management Act and Regulations 1999), the first of which has yet to be prepared. In the context of the Forest Accord, the provincial government, in cooperation with the public and various stakeholder groups, also produces fairly typical integrated forest land use plans for each of the province's forest management units (divisions of the provincial crown forest) every 5 years (Table 1). The 20year strategic plans and the operating plans produced by industry are also fairly typical of the Canadian provinces, except that the five-year and annual operating plans are merged: an operating plan must be submitted every year, and it must include detailed plans on the next five-year period but the most detail on the first of these years (Forest Resources Management Act 1996) (Table 1).

\section{Russia}

As in Canada, almost all of Russia's forest is federally owned (90\%, van Kooten and Vertinsky 1999, and management is legislated through the Russian Federation Forest Code (1997) and associated regulations. The Forest Code sets sustainable forest management as its main goal and discusses all but the global carbon cycle criteria; however, a 1998 policy guideline (Polozhenie ob arende uchastkov lesnogo fonda or Forest Lease Regulations) presents all six criteria, including global carbon cycles, as forest management goals. Forestry standards are set at the federal level, although in practice many of the management decisions are made at the regional level. Forest leases are issued by the local branch of the federal government on the recommendation of regional authorities. They range in term from one to 49 years. In the case of a lease of more than 200 ha and more than five years, the lessee must provide a landscape-level forest management and development plan within the first year of the lease, as well as stand-level logging plans every year (Table 1). If the lease is from two to five years, only logging plans are necessary. Both plans must be prepared by state foresters from the appropriate federal forestry body according to accepted normative standards, but are paid for by the lessee (Polozhenie ob arende uchastkov lesnogo fonda or Forest Lease Regulation 1998).

Like Canada's five-year operating plans, a forest management and development plan must contain a description of the characteristics of the forest and of all road-building and maintenance projects. It must include information on wildlife and vegetation and must outline how breeding grounds and the habitats of rare, endemic, and endangered species will be protected (Rosleskhoz 1994). It must also provide for the protection of any other special habitats, including riparian areas and small (less than $100 \mathrm{ha}$ ), relatively isolated forest stands found in prairies, gorges and ravines, etc. [O poryadke otneceniya lesnogo fonda $\mathrm{k}$ gruppam lecob u kategoriyam zashchutnosti or Regulations defining specially protected forest areas 1993 (updated in 1997)]. It must include a description of the harvest and silvicultural methods to be used and the size and shape of the blocks to be cut each year and must be submitted to the regional forestry office for approval (Rosleskhoz 1994). However, logging cannot begin without a logging license, and logging licenses are given out each year with the approval of the annual logging plan. Like all annual plans, this plan provides more detail on the specific stands to be logged and roads and methods to be used in the coming year, and it must be consistent with the longer-term forest management and development plan (Rosleskhoz 1994).

Although not discussed in the planning process requirements, the concept of multiple use and public access to the forest is firmly embedded in the 1997 Forest Code of the Russian Federation, which guarantees public access to the forest, regardless of any logging lease that may be in place. Citizens are given the right to collect wild fruits, berries, nuts, mushrooms and other edible forest resources, as well as medicinal plants, and to use the forest for hunting and recreation unless specifically outlawed by other legislation.

\section{Finland}

In Finland, $62 \%$ of the forest is under private family ownership, $9 \%$ is owned by companies, $24 \%$ by the state, and $5 \%$ by other owners such as municipalities (Finnish Forest Research Institute 1998). The private owners mostly own small forest stands (mean size $\sim 26$ ha), although there are some large private holdings ( $>500$ ha) (Finnish Forest Research Institute 1998). A large share of the annual industrial timber comes from these private forest owners ( $86 \%$ in 1999). Because the state forests are less fertile, the forest products industry tends to depend on private owners unless there are specific economic or logistical reasons to $\log$ the state forests (Finnish Forest Research Institute 1998).

The Forest Act (1997) applies to the management of all forest lands, not just those owned by the state. This legislation stresses ecological as well as economic sustainability, and discusses all but the global carbon cycle criterion of sustainable forest management, but the forest planning process itself is not legislated. The Forest Act requires only strategic regional-level planning under the Forestry Objective Program (Table 1). These forestry objectives are developed by the regional forestry centres (administered by various stakeholders, not by the government) in association with local forest owners and other stakeholders and with public input. They describe the forest and its resources and set general strategies to promote sustainable forest management in the region. The government then provides economic incentives for private owners to produce valid forest management operating plans on a smaller scale (Act on the Financing of Sustainable Forestry 1996). More than 75\% of the private forest land is covered by forest management plans and about $60 \%$ of the small forest owners use the government system (Nordic Council of Ministers 1999a). Meanwhile, 
more than $80 \%$ of the forest area is in compliance with the voluntary Finnish Forest Certification System (FFCS) (Finnish Forest Association 2000), which is set within the context of the criteria of sustainable forest management, although again without specific mention of the global carbon cycle. The FFSC criteria set requirements on the content of forestry objective programs and also on the coverage of forest estate-level planning (a minimum $50 \%$ of the forest area must be covered by forest management plans). As part of this certification, participating regional forestry centres must prepare the forestry objective programs required under the Forest Act at least every five years (Finnish Forest Association 2000) (Table 1). Most forest owners and forestry companies voluntarily prepare long-term landscape-level management plans (Nordic Council of Ministers 1999a). Many of the plans for private owners are produced at a low cost by the regional forestry centres (made up of stakeholder-group representatives) or forest owners associations. Industry and private consultants may also prepare management plans. Information from holding-level field surveys is used for planning and regional inventories (Nordic Council of Ministers 1999a).

A standard estate-level plan (i.e., for private owners) covers a period of 10 years in the south or 20 years in the north and examines the holding at a landscape or stand-level scale (Nordic Council of Ministers 1999a) (Table 1). To be considered valid, it must include maps and details on the site, age, and developmental stage of the forest, growing stock, proposed silvicultural treatments, regeneration operations, and any biotopes of conservation importance. These biotopes are described in the Forest Act (1997) and include riparian areas and wetlands, gorges and ravines, steep bluffs and the underlying forest, sandy soils, exposed bedrock, boulder fields, and flood meadows. In fact, the Forest Act specifies that these biotopes must be protected regardless of the planning process. It also specifies that landowners are responsible for insuring regeneration on logged stands.

The large forest-owning companies generally produce long-term and short-term plans (Table 1). At one of the largest companies, both landscape-level long-term (30-year) and stand-level short-term (10-year) plans are produced every year. The long-term plan is designed to ensure sustainability and determines the cutting level. It describes the present state of the forest, presents a plan for forest management, and provides a vision of the future forest under the described management regime, including distribution of age classes, timber volume, forest growth, and future forestry possibilities. The short-term plan describes the implementation of the long-term plan, presenting details on exactly what will be cut, where, and when. This plan also includes information on wood transportation (T. Suutarla, personal communication).

For logging on state-owned land, Metsähallitus (Finland's Forest and Park Service) has a three-level planning process (Table 1). This includes regional (100 $000-500000$ ha) natural resource management plans, which cover ten years and are revised every five years, landscape (40 $000-100000 \mathrm{ha})$ ecological plans, which cover at least 50 years and are reviewed every five years, and stand-level annual operating plans (Nordic Council of Ministers 1999a; I. Minkkinen, personal communication). The regional and landscape ecological plans provide broad-scale goals and objectives for land use and management, accounting for multiple uses. These planning pro- cesses involve extensive consultation with the public and other stakeholders such as environmental groups and local government authorities. The landscape ecological plans aim to protect natural areas, important habitats, threatened species, and ecological values while addressing economic and social objectives. The operating plans provide stand-level information on the blocks to be cut and the harvest and silvicultural methods to be used, with a particular focus on reforestation (I. Minkkinen, personal communication; Metsähallitus 2000).

\section{Sweden}

As in Finland, most of Sweden's forest is not state-owned: $51 \%$ is under private ownership, $33 \%$ belongs to forest products companies, $9 \%$ is state-owned, and $7 \%$ belongs to other land-owners such as municipal authorities and the Church of Sweden (Swedish Forest Industries Federation 1999). The private forest-owners of Sweden produce $61 \%$ of the total harvest volume (van Kooten et al. 1999). The forest management planning process is not largely legislated, and the Swedish Forestry Act (1993) makes no direct mention of sustainable forest management, although it does stress the importance of conserving biological diversity, soil and water, forest production capacity, and forest cover, and there are special processes for planned logging in "valuable broadleaved forests" and reindeer husbandry areas. Most of the large companies meet the Forest Stewardship Council (FSC) standards, which require long-term management plans and include the criteria of sustainable forest management in their list of main principles (Forest Stewardship Council 2000). Many Swedish forest owner organizations participate in the PEFC (Pan European Forest Certification), which also sets requirements for forest management planning directly within the context of the six Pan European criteria for sustainable forest management defined by the Helsinki Process. The PEFC criteria involve long-term and midterm planning, but do not specify that particular plans must be prepared at particular intervals to cover specific periods of time (Pan European Forest Certification Council 2000).

About $60 \%$ of forest owners prepare management plans (Nordic Council of Ministers 1999b). Most forest owners prepare medium-term (generally 10-year) forest management plans and companies also produce one- to three-year harvesting plans (Nordic Council of Ministers 1999b) (Table 1). Regardless of the planning process, forest owners must follow the Swedish Forestry Act (1993), which specifies that owners are responsible for regeneration and that the government may require ecological and cultural conservation measures and may regulate the shape and size of felling areas, regeneration methods, retention, fertilization, draining, and road-building.

A typical Swedish forest management plan sets long-term goals for forest production, nature conservation, and land use on a landscape level. It generally includes information on the soil, geology, climate, water and watershed, landscape preservation, biodiversity conservation, growing stock, tree species and age structure, habitat conservation, and other past and present uses of the proposed logging area. Companies may produce their own forest management plans, but those of private owners are often prepared by the Forest Owners Association or by the County Forestry Boards, which are headed by the National Board of Forestry (Nordic Council of Ministers 1999b). For FSC approval, forest management plans must contain clearly stated management objectives and a description 
of forest resources, silvicultural systems to be employed, monitoring, environmental safeguards based on environmental assessment, plans for identification and protection of rare and endangered species, as well as an explanation of the proposed annual rate of harvest and of tree species selection, supported by appropriate maps (Forest Stewardship Council 2000).

Some large companies have a more involved planning process (Table 1). For example, one of the five largest companies produces strategic plans every 10 years that consider a 100-year period, tactical plans every three to four years that cover a 10-year period, and operating plans at least once a year that consider a three-year period $(\mathrm{H}$. Troedsson, personal communication). Another of the largest companies has a similar process, with a strategic logging plan produced every 10 years to consider a 100-year period, another plan that covers three years, and annual operating plans (G. Bergqvist, personal communication). The long-term plan involves ecological landscape planning, including the identification of important habitat; the tactical plan includes the preliminary selection of stands to be logged and roads to be built and/or maintained; and the operating plan looks at logging, silviculture, and ecological conservation at the stand level.

\section{Commonalities among Political Jurisdictions}

There are a number of commonalities among the forest planning process in effect in most boreal jurisdictions.

a) All the legislation and certification criteria that regulate the forest management planning process include sustainable forest management as a main principle and stress the importance of at least five of the six sustainable forest management criteria set by the Montreal and Helsinki processes. The maintenance of global carbon cycles is often not mentioned, but all the planning systems require reforestation, which may or may not amount to the same thing in practice.

b) Not surprisingly, the planning hierarchy is more complex and regimented for public lands than for private lands. Forestry regulations for private lands primarily deal with practices and various assurances of the sustainability of timber production and environmental quality for the purposes of taxation, certification, and various forms of governmental assistance. Planning for public forest lands must also grapple with broader issues of policy, multiple forest values, resource emphasis zoning, and public input.

c) Commercial forestry development often takes place in the context of some kind of regional land use zoning. Historically, this zoning was often implicit rather than deliberate, i.e., wherever commercial timber was found in sufficient quantities and proximity to a transportation infrastructure, it was exploited. More recently, regional land use planning processes with varying degrees of public input have been used to allocate specific lands to timber production, or have excluded timber harvesting from areas (parks and reserves) designated for the protection of identified wildlife, biodiversity, or recreational opportunities. This is typically the most contentious of public involvement in forest planning: deciding where commercial timber harvesting should and should not occur.

d) Some kind of forest-wide (regional) plan is used to set the rate of cut and lay out the general goals of forest management, usually without the benefit of a complete inventory or a stageby-stage plan for activities over time. Some jurisdictions combine this level of planning with spatially explicit development plans, but the time frame varies from five or ten years to one or two rotations ( $140-200$ years).

e) As regional forest-level plans are gradually implemented to meet the stated goals of management, emphasis focuses on a few geographic areas in which roading, harvesting, and silvicultural activities will be concentrated in the near term. These medium-scale (landscape) plans are always spatially explicit, and represent the stage at which landscape ecology, analysis, and design feature into the optimization of both timber and conservation planning.

f) Stand-level or annual operating plans are the "marching orders" for implementation of forestry activities on the ground. They typically provide a detailed record of the ecological conditions and the engineering and silvicultural techniques to be employed at specific sites.

\section{Questions and Concerns Regarding the Standard Hierarchy of Forest Management Planning}

Although there is a good deal of discussion of sustainable forest management and the sustainable forest management criteria in the legislation and certification criteria that regulate the forest management planning processes across the boreal forest, it remains to be decided whether the systems in place actually lead to sustainable management. Specifically, we might ask:

- Whether it is appropriate to set the rate of cut and to enshrine forest-level objectives in licenses and contracts without complete inventories and without a full assessment of development and its impacts over time;

- Whether non-timber values are really being considered when the level of the harvest is set;

- Whether sustainability is really being effectively monitored;

- Whether forest planning should occur without explicit direction from higher-level land use plans, or whether land use planning should be part of the forest development process within designated forestry zones;

- How often plans of all scales should be revisited and revised to reflect better information, scientific knowledge, and changing conditions (environmental, social, and economic);

- Whether these planning hierarchies offer the correct balance of strategic "top-down" direction and "bottom-up" information, or whether they lead to development patterns inappropriate on the ground or opportunistic development that bears little relationship to forest management goals;

- At which stages of the planning process open public involvement is appropriate;

- When civil servants should be the active architects of forestry plans, as opposed to serving as resource people in their design, or serving as auditors and inspectors to assure sustainability.

We are obviously greatly in need of new landscape and regional planning tools to evaluate the long-term and large-scale impacts of various land uses. Within the context of sustainable forest management, these tools must evaluate multiple uses, including but not limited to forestry, and must consider impacts in terms of social and economic as well as environ- 
mental factors. Ongoing research attempts to identify indicators of sustainable forest management (e.g., Lautenschlager $\mathrm{et} \mathrm{al}$. 2000, Kneeshaw et al. 2000) should lead to the identification of such tools.

In Canada, the 20- to 25-year forest management plans are still based on the lease periods of the public forest and may have little bearing on actual environmental or even social and economic factors. From an ecological perspective, they do not cover the appropriate temporal scales necessary to evaluate the effect of the various management practices proposed on the ecological integrity of the forest at both the stand and landscape levels. It is promising that temporal scales of over 100 years are beginning to be considered across the boreal forest. These long-term and large-scale planning processes should be further developed and coupled with effective monitoring and impact assessment processes to consider how the proposed management will affect the ecosystem makeup of the region.

\section{Conclusion}

We have set forth the basic details of the hierarchical planning systems that have been brought into effect across the boreal forest in the past decade. These systems reflect an international tendency to steer away from sustained yield (timber supply) management in favour of the broader and more inclusive sustainable forest ecosystem management. However, the fact that all these systems consider sustainable forest management as a guiding principle does not necessarily indicate that the desired effects are achieved in practice. Furthermore, the process of identifying practical, measurable indicators of sustainable forest management is still ongoing. Identification of measurable indicators will lead to the development of mechanisms or tools to examine the consequences of the various temporal and spatial scales of planning on the ecological, social, and economic resources and uses of the forest over landscape and regional scales. Without these mechanisms, it is difficult to evaluate these planning systems in terms of sustainable forest management. We hope that this essay will stimulate discussion on the issue and that future research and management experience will be able to answer some of the questions we have raised.

\section{Acknowledgements}

This research was supported by the Network Centres of Excellence in Sustainable Forest Management. Special thanks go to P. Bédard (Ministère des ressources naturelles, Québec), G. Bergqvist (Holmen Skog, Sweden), A. Drozhzhin (Russia), I. Minkkinen [Metsähallitus (Forest and Park Service), Finland], L. Morgantini (Weyerhauser Canada Ltd.), H. Nikinmaa (Indufor, Finland), R. Spross [Skogsstyrelsen (National Board of Forestry), Sweden], R. St. Jean (British Columbia Forest Service), T. Suutarla (Stora Enso, Finland), and $\mathrm{H}$. Troedsson (Stora Enso, Sweden) for their aid in this research and for providing samples of forest management plans.

\section{References}

Alberta Environmental Protection. 1998. Interim Forest Management Planning Manual - Guidelines to Plan Development. Government of Alberta, Edmonton, AB. 46 p.

Alberta Pacific Forest Industries. 2000. Alberta-Pacific's Detailed Forest Management Plan. Alberta Pacific Forest Industries, Boyle, AB. 170 p.
British Columbia Ministry of Forests. 1996. Higher Level Plans: Policy and Procedures. Government of British Columbia, Victoria, BC. 80 p.

Canadian Forest Service. 2000. The State of Canada's Forests 1999-2000. Nat. Resour. Can., Can. For. Serv., Ottawa, ON. 123 p. Finnish Forest Association. 2000. Forest Certification in Finland. Helsinki, Finland. Available at http://www.ffcs-finland.org/eng/ index.htm.

Finnish Forest Research Institute. 1998. Finnish Statistical Yearbook of Forestry. Finnish Forest Research Institute, Helsinki, Finland. 366 p.

Forest Stewardship Council. 2000. FSC Principles and Criteria. Forest Stewardship Council, Oaxaca, Mexico. 10 p. Available at http://www.fscoax.org/principal.htm

Kneeshaw, D., A. Leduc, P. Drapeau, S. Gauthier, D. Paré, R. Doucet, R. Carignan, L. Bouthillier and C. Messier. 2000. Development of integrated ecological standards of sustainable forest management at an operational scale. For. Chron. 76: 481-493.

Lautenschlager, R.A., H. MacLeod, C. Hollstedt and D. Balsillie. 2000. Examining the specifics approach to identifying indicators of sustainable natural resource management in Ontario, Saskatchewan, and British Columbia. For. Chron. 76(5): 725-737.

Metsähallitus (Forest and Park Service). 2000. Landscape Ecological Planning. Metsähallitus (Forest and Park Service), Helsinki, Finland. 9 p.

Montreal Process. 1995. Criteria and indicators for the conservation and sustainable management of temperate and boreal forests: the Montreal Process. Can. For. Serv., Hull, QC. 27 p.

Nordic Council of Ministers. 1999a. Forest Planning in Finland. In Forest Planning Today in the Nordic Countries and Scotland. pp. 9-18. Nordic Council of Ministers, Copenhagen.

Nordic Council of Ministers. 1999b. Forest Planning in Sweden. In Forest Planning Today in the Nordic Countries and Scotland. pp. 3-8. Nordic Council of Ministers, Copenhagen.

Pan European Forest Certification Council. 2000. Pan European Forest Certification Framework: Common Elements and Requirements, Technical Document. The Pan European Forest Certification Council, Luxembourg. 5 p.

Rosleskhoz (Russian Ministry of Forests). 1994. Skhemu tipovogo proekta organizatsii rubok glavnogo pol'zovaniya i vedeniya lesnogo khozyaistva na apenduemykh uchastkakh lesnogo fonda (Outline of a typical forest management plan in leased areas). Government of the Russian Federation, Moscow, Russia. Order \#123. 37 p. Swedish Forest Industries Federation. 1999. The Swedish Forest Industry Facts and Figures. Stockholm, Sweden. 20 p.

United Nations Commission on Sustainable Development. 1996. Scientific research, forest assessment and development of criteria and indicators for sustainable forest management, Programme element III.2: Criteria and indicators for sustainable forest management. United Nations Commission on Sustainable Development. 27 p. Available at http://www.un.org.

van Kooten, G.C. and I. Vertinsky. 1999. Introduction: A framework for forest policy comparison. In B. Wilson, G.C. van Kooten, I. Vertinsky and L. Arthur (eds.). Forest Policy - International Case Studies, pp. 1-22. CABI Publishing, Wallingford, UK.

van Kooten, G.C., B. Wilson, and I. Vertinsky. 1999. Chapter 7: Sweden. In B. Wilson, G.C. van Kooten, I. Vertinsky and L. Arthur (eds.). Forest Policy - International Case Studies, pp. 155-185. CABI Publishing, Wallingford, UK. 